\title{
Candidate Ethnicity and Vote Choice in Britain
}

Stephen D. Fisher

Department of Sociology, University of Oxford

(Email for corresponding author: stephen.fisher@trinity.ox.ac.uk)

Anthony F. Heath

Institute for Social Change, University of Manchester and Department of Sociology, University of Oxford

David Sanders

Department of Government, University of Essex

Maria Sobolewska

School of Social Sciences, University of Manchester

Manuscript accepted for publication by the British Journal of Political Science

\section{Acknowledgements}

The authors would like to thank Per Block and Nicole Martin for assistance with the coding of candidate ethnicity, and to Jonathan Mellon for help with census data. Previous versions of this paper were presented in Manchester, Oxford and at the ECPR General Conference in Reykjavik, and we are grateful to participants at those events, especially Jean Benoit Pilet, and also to Nicole Martin, Michael Traugott and the anonymous reviewers for helpful comments. This work was supported by funding from the ESRC award ES/G038341/1. 


\title{
Candidate Ethnicity and Vote Choice in Britain
}

\begin{abstract}
This paper develops and tests a set of theoretical mechanisms by which candidate ethnicity may have affected the party vote choice of both White British and ethnic minority voters at the 2010 British General Election. Ethnic minority candidates suffered an average electoral penalty of about 4 per cent of the three-party vote from Whites, mostly as a result of those with anti-immigrant feelings being less willing to vote for Muslims. Ethnic minority voter responses to candidate ethnicity differed by ethnic group. There were no significant effects for non-Muslim Indian and Black voters, while Pakistani candidates benefitted from an 8 point average electoral bonus from Pakistani voters.
\end{abstract}

\section{Introduction}

Ethnic minorities are consistently under-represented in all democracies ${ }^{1}$ and this may be in part because majority voters discriminate against minority candidates. $^{2}$ Conversely there is research showing that visible minorities are more likely to vote for members of their own ethnic or racial group in the $\mathrm{US}^{3}$ and in proportional representation systems that allow preference voting. ${ }^{4}$ While there is also evidence that candidate ethnicity affects voting in British elections, with one exception ${ }^{5}$ it has thus far been based on aggregate data or qualitative reports. There are also some interesting questions about the effects of candidate ethnicity that arise from the

\footnotetext{
${ }^{1}$ Bird et al. 2011; Ruedin 2009.

${ }^{2}$ E.g. Lewis-Beck et al. 2010; Terkildsen 1993.

${ }^{3}$ E.g. Barreto 2007; Bobo and Gilliam 1990; Collet 2005; Philpot and Walton 2007; Wolfinger 1965.

${ }^{4}$ E.g. Berg and Bjoklund 2011; Michon and Tillie 2011; Teney 2010, although Highton (2004) finds otherwise.

${ }^{5}$ Stegmaier et al. 2013.
} 
British context that can only now be addressed with high quality individual-level survey data from the 2010 Ethnic Minority British Election Study. This paper considers whether White British voters are more reluctant to vote for non-White candidates, and whether ethnic minority voters are more inclined to support nonWhite candidates, perhaps especially those from the same ethnic group.

White British people perceive different minority groups differently, with Muslims receiving among the most hostile reactions. ${ }^{6}$ The terrorist attacks on $11^{\text {th }}$ September 2001 in New York and on $7^{\text {th }}$ July 2005 in London heightened Islamophobia. ${ }^{7}$ There have been claims that bigotry against Muslims is now socially acceptable. ${ }^{8}$ So this paper considers whether Muslim candidates in particular suffer an electoral penalty from White voters, but also whether Muslim voters are more likely to support Muslim candidates. ${ }^{9}$

The next section outlines some important features of the context before we discuss previous research and possible mechanisms by which candidate ethnicity might affect vote choice. The data and methodology sections then precede the results and concluding discussion.

\section{Background on ethnicity in British electoral politics}

The five main non-White minority groups as identified in the Census question on ethnicity are Indian, Pakistani, Bangladeshi, Black Caribbean, and Black African,

\footnotetext{
${ }^{6}$ Ford 2011.

${ }^{7}$ Field 2011.

${ }^{8}$ Kirkup 2011.

${ }^{9}$ While it would be interesting to be able to explore candidate religion effects more generally the available data are inadequate.
} 
and together they probably made up around eight per cent of the electorate in $2010 .^{10}$ With the exception of some first generation Black Africans from nonCommonwealth countries, members of these groups are all entitled to vote and, if registered, they tend to vote at similar rates to the White British majority. ${ }^{11}$ They have also consistently been much more likely to vote Labour than Whites, ${ }^{12}$ perhaps mainly because all of the legislation advancing the rights and opportunities of ethnic minorities has been passed by Labour governments. ${ }^{13}$

As in other Western countries, there is evidence of discrimination against non-White ethnic minorities in the labour market in Britain. ${ }^{14}$ Since the British Social Attitudes surveys began in 1985 they have shown around 30 per cent admitting to being at least somewhat 'prejudiced against people from other races' with relatively little variation. ${ }^{15}$ This context raises the question as to whether ethnic minorities are at a disadvantage in the political arena as a result of prejudice and discrimination.

There were record numbers of ethnic minority candidates standing and elected in 2010 (see Table 1). However, twenty-seven MPs constitute just four per cent of the total, less than half of the proportion of ethnic minorities in the population as a whole. ${ }^{16}$ Most of the increase in the number of ethnic minority MPs between 2005

\footnotetext{
${ }^{10}$ Heath et al. 2011.

${ }^{11}$ Heath et al. 2011.

${ }^{12}$ Saggar and Heath 1999.

${ }^{13}$ Heath et al. 2013.

${ }^{14}$ Wood et al. 2009.

${ }^{15}$ Creegan and Robinson 2008.

${ }^{16}$ Table 1 includes minorities from groups other than the five main ones and those of mixed origin. The size of the comparable group in the electorate is hard to estimate but is likely to be at least nine per cent.
} 
and 2010 can be accounted for not by the simple increase in the number of such candidates, but by a new strategy by the Conservatives to ensure several were placed in safe seats. ${ }^{17}$

\section{TABLE 1 ABOUT HERE}

Before minority candidates face a penalty at the hand of the electorate, they may also be subject to particular difficulties and prejudice at the stage of becoming candidates in the first place. ${ }^{18}$ As a result those minority candidates who do survive the selection process are likely to be at least as good if not better quality candidates than their White counterparts. Many will have important experience as a local councillor ${ }^{19}$ or strong local support, especially in relatively high minority-density areas. ${ }^{20}$

\section{Previous research on the effects of candidate ethnicity in Britain}

Until recent elections there have not been sufficient numbers of ethnic minority candidates for systematic analysis, however there were various cases where nonWhite candidates appear to have done especially badly in the polls because of their race or ethnicity. The failure of the Black Conservative candidate John Taylor to win Cheltenham in 1992 is perhaps the most famous example. More comprehensive analysis of aggregate constituency election results shows that minority candidates from both the Conservatives and Labour did worse (in terms of change in the constituency share of the vote since the previous election) than other candidates from

\footnotetext{
${ }^{17}$ Sobolewska 2013.

${ }^{18}$ Geddes 1995; Norris et al. 1992.

${ }^{19}$ Geddes 2001.

${ }^{20}$ Le Lohé 1998; Laurence and Maxwell 2012.
} 
their parties in the 1987, 1992 and 1997 elections. ${ }^{21}$ Looking at how, between 1997 and 2001, changes in the share of the vote across constituencies varied according to changes in ethnic status of the candidates, Mortimore found that ethnic minority candidates from Labour and the Liberal Democrats suffered an electoral penalty, but that Conservatives did not. ${ }^{22}$ Similar analysis for 2005 suggested that ethnicminority Conservative candidates fared less well than others from their party, but this was not so for Labour ethnic-minority candidates. ${ }^{23}$ For the 2010 election, Stegmaier et al. found candidate ethnicity effects whereby incumbent party candidates benefited from having a minority challenger. ${ }^{24}$ Also, Curtice et al. show that the fortunes of ethnic-minority candidates relative to others from their party were sensitive to the ethnic composition of the constituencies. ${ }^{25}$ Minority candidates from both the Conservative and Labour parties did worse than White candidates in areas with few non-White residents but in constituencies with large minority populations being an ethnic minority candidate seemed to bring a slight advantage. ${ }^{26}$

While these studies do not find consistent candidate ethnicity effects for all parties at all elections, this could be because the methodology relies on infrequent changes in ethnicity of a party's candidate to identify effects. The accumulated evidence suggests that White voters discriminate against non-White candidates while ethnicminority voters may favour them. However, the ecological inference problem ${ }^{27}$

\footnotetext{
${ }^{21}$ Le Lohé 1993, Saggar and Geddes 2000.

${ }^{22}$ Mortimore 2002.

${ }^{23}$ Curtice et al. 2005.

${ }^{24}$ Stegmaier et al. 2013.

${ }^{25}$ Curtice et al. 2010.

${ }^{26}$ There was no clear pattern for Liberal Democrats by candidate ethnicity.

${ }^{27}$ Robinson 1950.
} 
means that we cannot necessarily draw this conclusion from the above-mentioned studies, with the exception of Stegmaier et al. who look at both aggregate and individual-level data. ${ }^{28}$ Most recently, an internet survey experiment showed a small negative effect of being Muslim, but on evaluations of hypothetical candidates rather than actual votes of non-Muslims. ${ }^{29}$

In addition to White/non-White candidate effects, there is some sporadic evidence that in areas with large ethnic minority populations the particular ethnicity of a minority candidate can affect electoral performance. For example, in 1997 despite an 11 percentage point fall nationally in the Conservative share of the vote, the party were up by 5 points in Bethnal Green and Bow and down by less than a point in Bradford West. Both seats have large Muslim populations and saw Conservative Muslim candidates stand against non-Muslim Labour candidates. ${ }^{30}$ In Bethnal Green and Bow the Labour candidate, Oona King, was from a mixed Jewish and African American background, while in Bradford West Labour fielded an Indian Sikh after a tense selection process. Examples such as these suggest that ethnic minority voters may prefer to vote for a co-ethnic candidate or one with the same religion, but in addition to the ecological inference problem the aggregate data on this issue are sparser.

\section{Social mechanisms that might generate or moderate candidate ethnicity effects}

\footnotetext{
${ }^{28}$ Stegmaier et al. 2013. This article effectively builds on that work by developing further theory, testing different ethno-religious group effects and additional mechanisms, and by considering the behaviour of White and minority voters separately. This research also differs in the choice of individual-level data and the coverage of constituencies.

${ }^{29}$ Campbell and Cowley 2013.

${ }^{30}$ Curtice and Steed 1997; Geddes 2001.
} 
The general phenomenon that this paper investigates is voting, by both White and ethnic minority voters, in favour or against candidates according to their ethnic or religious characteristics. There are numerous mechanisms that might generate or moderate such candidate ethnicity effects. We start by discussing symmetrical and then asymmetrical mechanisms, before turning to group specific issues and finally potential moderating factors.

\section{Symmetrical mechanisms}

Sensitivity to candidate ethnicity may be driven by mechanisms that are symmetrical in the sense that they can, at least theoretically, apply to all groups and lead each group to favour its own to a similar extent. There are various potential symmetrical mechanisms for candidate ethnicity effects. First, there is pure prejudice for one's own group, what Becker described as a 'taste for discrimination'. ${ }^{31}$ A second possibility is that a voter might favour a candidate of the same ethnicity or religion in the belief that such a candidate will represent their views and interests better on the basis of shared experience. Third, voters may trust co-ethnics (as in-group members) more than they do members of ethnic out-groups because of a shared social identity. In addition to trust, the social psychology literature also suggests in-group members are likely to benefit from other positive attitudes, emotions and affect. ${ }^{32}$ For example, Tate found that Black candidates sparked group loyalty, pride and political interest among Black citizens in the US. ${ }^{33}$ A fourth mechanism suggests that voters are more likely to be mobilized by co-ethnic candidates, ${ }^{34}$ perhaps because of their social networks or bonding social capital. In the US there is evidence that minority

\footnotetext{
${ }^{31}$ Becker 1957.

${ }^{32}$ Hewstone et al. 2002; Tajfel 1981; Voci 2010.

${ }^{33}$ Tate 1991.

${ }^{34}$ Banducci et al. 2004.
} 
candidates focus on voters from their group as core supporters and devote more effort to mobilizing them. ${ }^{35}$

While these mechanisms are theoretically symmetrical, since they might be equally applicable for all groups, in practice whether and how they operate is likely to depend on the groups involved and the context. More generally, because the overwhelming majority of candidates and MPs are White, minority candidates are likely to be seen by all kinds of voters as, to some extent, exceptional. This is true even in areas with large concentrations of minorities. ${ }^{36}$ So it is more appropriate to ask about the extent to which different groups of voters choose in favour or against different kinds of ethnic minority candidates, than it is to look for symmetrical patterns of preference for in-group over out-group members.

\section{Asymmetrical mechanisms}

In addition to mechanisms that in theory are symmetrical but in practice might not be, there are mechanisms that might have asymmetrical candidate ethnicity effects even in theory. One of these would be an analogy to the idea of 'statistical

\footnotetext{
${ }^{35}$ E.g. Butler and Broockman 2011; Griffin and Keane 2006; Leighley 2001. Effects on turnout are the subject of a separate paper in progress by a colleague. While Fieldhouse and Cutts (2008) found no effects of Asian candidature on ethnic minority turnout, preliminary results for our colleague's paper suggest some co-ethnic effects that concord with this paper. The analysis in this paper cannot straightforwardly be extended to encompass turnout as another voting option, not least because of the party-specific variables. The results here may partly and legitimately reflect mobilization effects but since independence of irrelevant alternatives (IIA) is not assumed they should not be biased by a lack of simultaneous turnout modeling.

${ }^{36}$ Only four constituencies (Bethnal Green \& Bow, Birmingham Ladywood, Ealing Southall and Tooting) had minority candidates from all three main parties, but 6 of the 20 most diverse constituencies were contested by White candidates from all the three main parties.
} 
discrimination' in the labour market whereby employers discriminate on the basis of assumed productivity differences between ethnic or racial groups that cannot be linked to observable objective characteristics, such as educational attainment. ${ }^{37}$ The analogous mechanism for electoral politics would suppose that candidates from different ethnic groups are not equally good (at least on average) at the generic tasks of being an MP, such as responding to the concerns of constituents. There is evidence from Canada and the US that candidate quality affects electoral performance. ${ }^{38}$ But without being able to control for candidate quality, we might expect all groups of voters to favour the ethnic group that fields on average the best candidates. As mentioned above, ethnic minority candidates are likely to be more positively selected on quality than Whites. If so, then statistical discrimination (by White and minority voters) should be in favour of minority candidates as they are likely to be better, on average, than White candidates.

A second asymmetrical mechanism is that candidate ethnicity might act as a heuristic for a candidate's traits, values or ideology in the context of a constituency contest in which British voters typically know very little about the candidates. ${ }^{39}$ While in the US, voters perceive ideological and character differences between candidates according to race and minority legislators do act more as trustees for minority interests, ${ }^{40}$ in Britain, Buttice and Milazzo find only insignificant effects of race on ideological distance between the top two candidates in a constituency. ${ }^{41}$

\footnotetext{
${ }^{37}$ Arrow 1998.

${ }^{38}$ E.g. Black and Erickson 2006; Jacobson 1989; Lublin 1994; Squire 1992.

${ }^{39}$ Cutler 2002.

${ }^{40}$ Juenke and Preuhs 2012; McDermott 1998; Sigelman et al. 1995.

${ }^{41}$ Buttice and Milazzo 2011. Also the mechanism provides plenty of scope for candidates from one group to attract votes of another and it is not explicitly testable with our data.
} 


\section{Group specific issues}

The direction and strength of all the mechanisms described above could vary according to the specific ethnic or religious identities of the voters and candidates in question. Ford shows that Whites are more opposed to immigration from South Asia than the West Indies. ${ }^{42}$ We also expect Whites to be especially unlikely to vote for Muslim candidates. Discrimination may be stronger because of greater social distance and distrust, often labelled Islamophobia. ${ }^{43}$ In the US, Benson et al. found that 40 per cent of survey respondents said they would be unwilling to vote for a Muslim candidate for President, and in their experimental study, Muslims, along with Atheists, were the most discriminated against groups. ${ }^{44}$ In their comparison of attitudes to religion in US and Britain, Voas and Ling found similarly negative attitudes to Islam in Britain as in the US. ${ }^{45}$ Various opinion polls in Britain have also reported hostility to Islam, with around 50 per cent in 2006 and 2011 seeing Islam as a threat to western liberal democracy. ${ }^{46}$

Although far from being a single homogenous group with a strong shared non-White immigrant-origin identity, shared status and experience as visible minorities create a common interest in and concern for anti-discrimination legislation and race-relations policy which may lead non-White voters to disproportionately support ethnic minority candidates generally. But minorities are perhaps most likely to vote for candidates from their own ethnic group. Such co-ethnic voting is likely to be

\footnotetext{
${ }^{42}$ Ford 2011.

${ }^{43}$ Field 2011.

${ }^{44}$ Benson et al. 2011.

${ }^{45}$ Voas and Ling 2008.

${ }^{46}$ Wells 2011.
} 
stronger for Asian groups due to higher rates of intermarriage, ${ }^{47}$ geographical segregation $^{48}$ and political organization ${ }^{49}$ than Black groups. Laurence and Maxwell in their broad discussion of immigrant incorporation into European politics remarked specifically on the extent to which Pakistanis and Bangladeshis in Britain have successfully organized and mobilized their own communities to elect their own members. ${ }^{50}$ Similarly, Solomos and Back and Garbaye note that their qualitative research suggests voting based on kinship networks is particularly strong among Pakistanis, ${ }^{51}$ commonly referred to as part of the biraderi system.

Co-ethnic loyalties might even lead to discrimination against non-coethnic minority candidates. ${ }^{52}$ For example, the attitudes of some people of Indian, Bangladeshi and Pakistani descent sometimes reflect the hostile sentiments of people in those countries to each other. There have also been tensions between Asian and Black groups, including violence, such as in the 2005 Lozells riots. The Bradford West and Bethnal Green and Bow 1997 constituency results discussed above suggest that these differences may be important in elections.

Alongside ethnic identities, minority religious identities, especially Islam, may be the source of electoral support for in-group candidates. Islamophobia may provoke particularly strong solidarity among Muslims in Britain. But even without this, Muslims share strong religious beliefs, identity and policy concerns which could

\footnotetext{
${ }^{47}$ Muttarak and Heath 2010.

${ }^{48}$ Peach 2009.

${ }^{49}$ Dancygier 2010.

${ }^{50}$ Laurence and Maxwell 2012.

${ }^{51}$ Garbaye 2002; Solomos and Back 1995.

${ }^{52}$ Le Lohé 1998.
} 
lead Muslim voters to support Muslim candidates. Mosques and Islamic organizations may reinforce these. Statham (1999) argues that the Muslim identity is much stronger than the (South) Asian one as a basis for political claims making, ${ }^{53}$ in part because Hindus and Sikhs have been more economically successful. ${ }^{54}$

\section{Potential moderating factors}

To add to the complex set of potential mechanisms that might generate candidate ethnicity effects, there are also a series of factors that might moderate the strength of any candidate ethnicity effects. Such processes would be observed as interaction terms with candidate characteristics.

Firstly, for both Whites and minorities, we expect to see greater discrimination against out-group candidates among those who are more generally prejudiced against ethnic out-groups. ${ }^{55}$ In addition, for ethnic minorities, strength of in-group identity and perceived racial discrimination may also be associated with greater support for co-ethnic or non-White candidates. Given recent debates about a backlash against the biraderi system, co-ethnic voting might be weaker for young and secondgeneration Pakistanis. ${ }^{56}$

Second, preferences for descriptive (or symbolic) representation may have a moderating effect. There have been both advocacy organizations and an all-party committee of MPs calling for policies to improve the representation of ethnic

\footnotetext{
${ }^{53}$ Statham 1999.

${ }^{54}$ Modood 1992.

${ }^{55}$ Kam 2007.

${ }^{56}$ Goodhart 2012.
} 
minorities in the House of Commons. ${ }^{57}$ The 2010 Ethnic Minority British Election Study (EMBES) found that 43 per cent of respondents agreed that 'Black and Asian MPs can better represent Black and Asian interests than White MPs can.' Similarly, 60 per cent agreed that, 'Getting more Black and Asian people into Parliament would improve things for ethnic minorities in Britain. ${ }^{58}$ There should also be stronger candidate ethnicity effects for minority voters with these views.

Third, discrimination by Whites against non-White candidates might be weaker in constituencies with larger proportions of ethnic minority voters, along the lines found in the US, ${ }^{59}$ perhaps as a result of social contact reducing social distance ${ }^{60}$ or greater acceptance of minority candidates. ${ }^{61}$ Alternatively, the racial threat hypothesis suggests that more diverse areas lead Whites to become more hostile to minorities and so less likely to vote for minority candidates. ${ }^{62}$ In line with this argument, hostility towards Muslims in Britain and voting for xenophobic parties is greater in areas with more Muslim residents. ${ }^{63}$ This provides reason to expect a negative moderating effect of ethnic composition, but one that should decline after controlling for attitudes to minorities.

A fourth potentially moderating effect is constituency competitiveness. Voters should be less willing to compromise on voting for a party that best represents their

\footnotetext{
${ }^{57}$ Operation Black Vote 2008; Speaker's Conference on Parliamentary Representation 2009.

${ }^{58}$ See Cowley (2013) for further evidence.

${ }^{59}$ Carsey 1995.

${ }^{60}$ Allport 1954; Pettigrew 1998.

${ }^{61}$ Geddes 2001.

${ }^{62}$ Avery and Fine 2011.

${ }^{63}$ Bowyer 2009; Ford and Goodwin 2010.
} 
views if there is serious competition for who actually gets elected. So candidate ethnicity effects ought to be weaker in constituencies where the winner had a relatively narrow margin of victory. Similarly with strong incentives to desert candidates running in third or lower place, candidate ethnicity might become a relatively stronger factor with greater distance from contention. Finally, incumbents are likely to be better known to their constituents, so their ethnicity is less likely to be used as a heuristic for judgements on their character, abilities or values.

To the extent that the British case can be viewed in comparative perspective one could also note that political institutions and social context also act as moderating variables. By comparison with most other European countries, where proportional representation is used, candidate ethnicity effects in Britain's simple plurality electoral system inevitably take a different form. While the US has the same electoral system, the context of race and ethnicity is so different and the link between district ethnic composition and descriptive representation is so much stronger ${ }^{64}$ that there is no question as to whether there are candidate ethnicity effects. Also, whereas in Britain's parliamentary system the high levels of legislative party cohesion mean that policy outcomes depend almost entirely on which (usually single) party forms the government, candidate traits and ideology are clearly more important and legitimate concerns in US electoral behaviour because parties are weak and legislators frequently vote against their party. Although there are important differences, Canada is probably the most comparable country to Britain in terms of the political institutions and experience of non-White immigration. Canadian studies have typically found no significant candidate ethnicity effects, ${ }^{65}$ and so we should perhaps expect similar null findings for Britain given the similar importance of

\footnotetext{
${ }^{64}$ E.g. Lublin et al. 2009.

${ }^{65}$ E.g. Black and Erikson 2006.
} 
parties. However this does mean that if there are candidate ethnicity effects after controlling for factors affecting party preference they are particularly interesting since they suggest voters are even willing to compromise on substantive representation in order to avoid voting for candidates from particular ethnic groups.

With the available data we can test for all of the different mechanisms and moderating factors above apart from those involving candidate quality and traits, or perceptions of candidates, for which we have no adequate measures. We are, however, able to test for presence of candidate (co-)ethnicity and (co-)Muslim identity effects, and the extent to which these effects are mediated by contact with parties and co-ethnic activists or moderated by attitudes to immigration as a proxy for Islamophobia (for Whites); by group identity measures and attitudes to descriptive representation (for minorities); by the ethnic composition of the constituency; by the competitiveness of the district; by distance from contention; and by incumbency.

\section{Data}

Information on the ethnicity and religion of candidates comes from various sources, including the BBC, The Guardian and Pippa Norris. ${ }^{66}$ They have been cross-checked and supplemented with searches for candidate websites and other online information. Candidates were coded as ethnic minorities if there was public information stating their background as such. These included candidates with mixed White and nonWhite minority backgrounds. Coding of the five main non-White minority groups sometimes relied on analysis of names and appearance. There were 45 Indian, 42 Pakistani, 7 Bangladeshi, 11 Black Caribbean, 15 Black African and 17 other ethnic

\footnotetext{
${ }^{66}$ Norris 2010.
} 
minority candidates for the three main parties, with similar distributions for each party. ${ }^{67}$ Relative to their proportions in the electorate it is most striking how few Black Caribbean candidates there were.

It was possible to identify Muslim candidates mainly because of discussion on websites as to which candidates were Muslim. There were 16 Conservative, 19 Labour and 20 Liberal Democrat Muslim candidates, constituting 3 per cent of major party candidates. ${ }^{68}$ It was not possible to consistently identify candidate membership of other religions, which is why this paper does not consider candidate religion effects more generally.

Party constituency spending data are from the Electoral Commission. Data for other constituency-level characteristics come from the authors of Curtice et al. ${ }^{69}$ These include election results, constituency census data, incumbency status and measures of the severity of the MPs expenses scandal.

The individual-level data on White voters come from the British Election Study (BES) campaign internet panel for $2010 .^{70}$ Data on ethnic-minority voters are drawn

\footnotetext{
${ }^{67}$ Candidates of mixed origin (White/other) were coded according to the minority group one of their parents came from.

${ }^{68}$ Our coding takes no consideration of whether the person actively practices or publically professes belief in Islam, but equally very few ethnic minorities in Britain claim not to have a religion and we know of no cases of apostasy by candidates with Muslim backgrounds.

${ }^{69}$ Curtice et al. 2010.

${ }^{70}$ Clarke et al. 2010. These data were chosen to maximize variance on the candidate ethnicity variables. They cover 630 of the 632 GB constituencies whereas the BES face-to-face survey used by Stegmaier et al. (2013) includes only 200.
} 
from both the BES face-to-face post-election survey ${ }^{71}$ and the Ethnic Minority British Election Study (EMBES) 2010 survey, ${ }^{72}$ which is based on a face-to-face probability sample of the five main minority groups in Britain; Black African, Black Caribbean, Indian, Bangladeshi and Pakistani. The survey has at least 90 per cent coverage of these populations, but it is disproportionately drawn from areas with high ethnic minority populations.

\section{Methods}

The statistical models used to estimate the effects of candidate ethnicity are alternative-specific multinomial probit models. ${ }^{73}$ The model uses stacked data, with three rows for each respondent, one for each party. Let $\mathbf{x}_{i p}$ be a matrix of alternativespecific variables (i.e. party-respondent combination specific such as leader ratings) and $\varepsilon_{i p}$ be a normally distributed error term, then the utility for voter $i$ of voting for a particular party $p=1,2$ or 3 , can be represented as,

$u_{i p}=\mathbf{x}_{i p} \beta+\varepsilon_{i p}$

The probability that voter $i$ chooses party $p$ is

$\operatorname{Pr}\left(y_{i}=p\right)=\operatorname{Pr}\left(u_{i p}>u_{i q}\right.$ for all $\left.q \neq p\right)$.

This model differs from the conditional logit model in the functional form of the distribution of the error term and, more importantly, in allowing the errors to be correlated and thus relaxing the independence of irrelevant alternatives (IIA)

\footnotetext{
${ }^{71}$ Clarke et al. 2012.

${ }^{72}$ Heath et al. 2012.

${ }^{73}$ Long and Freese 2005.
} 
condition. ${ }^{74}$ Likelihood ratio tests for the violation of IIA proved highly statistically significant, but the choice of alternative-specific multinomial probit over conditional logit had implications only for the statistical significance of two control variables and no implications for the substantive conclusions regarding candidate ethnicity effects. All the main conclusions are robust to exclusion of Scotland and Wales or any single constituency. ${ }^{75}$

This model is similar to a multinomial probit model but it allows alternative specific variables as predictors. This enables a single coefficient for the effects of candidate ethnicity, or co-ethnicity, to be estimated regardless of the candidate's party. However, we also tested for evidence of variation in these coefficients across parties. The model set up provides for estimates and predicted probabilities to be appropriately sensitive to different candidature patterns within constituencies (e.g. three minority candidates, one Muslim, one non-Muslim minority and one White candidate etc.) but a modelling strategy that singles out particular combinations would be problematic because of the paucity of cases for any particular combination.

For White respondents we consider the effects of a party having an ethnic minority candidate, of having a Muslim candidate and of having a candidate of a particular ethnic group. For ethnic minority voters we consider the effects of having an ethnic minority candidate, a co-ethnic candidate, a Muslim candidate and a co-Muslim candidate. Thus the co-ethnic candidate variable takes the value 1 when the party has a candidate of the same ethnicity (Indian, Pakistani, Bangladeshi, Black Caribbean or Black African) as the respondent, and 0 otherwise. Similarly the $c o$ -

\footnotetext{
${ }^{74}$ Train 2003.

${ }^{75}$ There were too few ethnic minority candidates in Scotland and Wales to analyse these countries separately.
} 
Muslim candidate variable is 1 only when both the candidate and the respondent were Muslim, and is otherwise 0 .

In the interests of parsimony, the models below include only statistically significant variables that have also been established by previous research. ${ }^{76}$ The control variables present in the models for both Whites and ethnic minorities are Strength of party identification (a four-point scale from $0=$ not an identifier, through to $3=$ very strongly identify with the party); Party like score (an eleven-point scale from $0=$ strongly dislike to $10=$ strongly like the party $)$; Leader like score $(0=$ strongly dislike to $10=$ strongly like the party leader); Party best on the most important issue ( 1 if the party was thought to be the best to solve what the respondent felt was the most important issue, and 0 otherwise); Contacted by party (1 if the respondent was contacted by the party during the campaign, or 0 otherwise); and finally to capture Duvergerian strategic voting incentives, Distance from Contention (for third and lower placed parties this is the difference between the 2010 share of the vote for the party and that for the second-placed party, and 0 if the party came first or second in the constituency). All of these are alternative-specific, so their values can vary across the party options for a given respondent.

Although party contact and orientations to parties and leaders are potential mediating factors between candidate ethnicity and vote choice, their inclusion in the model makes little difference to the estimated candidate effects. While candidate ethnicity effects may operate in part through perceptions of parties, the danger from exclusion of attitudinal variables is that candidate ethnicity coefficients then more likely reflect the extent to which certain candidates stood where their party was (un)popular with

\footnotetext{
${ }^{76}$ The set of all the potential control variables tested is sufficiently large that including all made parameter estimates unstable and incomprehensible.
} 
particular groups (i.e. the attitudinal variables help resolve a potential selection bias or non-random allocation problem).

Several other potential controls were also considered but found to be insignificant, ${ }^{77}$ most likely because their effects are mediated by variables more proximate to vote choice in the causal chains. A few variables were statistically significant for the Whites model but not for minorities (Public Sector employment, Incumbent MP and Short Campaign Spend as a proportion of the legal limit ${ }^{78}$ ) and vice versa (region, operationalized as resident in Scotland, Wales or the North of England). Where a control variable (say $\mathrm{X}$ ) is respondent-specific two coefficients are estimated $\left(C^{*}{ }^{*} \mathrm{X}\right.$ and $\left.L D^{*} \mathrm{X}\right)$, for the effects on voting Conservative and Liberal Democrat respectively, each relative to the baseline Labour (just as a regular multinomial logit/probit model would have two such coefficients).

The only attitudinal variable that was considered as a potential moderator of

\footnotetext{
${ }^{77}$ For both Whites and non-Whites these included class, religion, religiosity, education, trade union membership, housing tenure, age, gender, constituency marginality, UKIP campaign spending and constituency percentage non-White and percentage Muslim. In addition to these, for minorities other controls which were also considered, but were insignificant, were ethnic group (Indian, Pakistani, Bangladeshi, Black Caribbean, Black African or other), relative strength of British/Ethnic identity, relative strength of British/religious identity, immigration generation (whether the respondent was an adult immigrant, child immigrant, the child of immigrants or child of British born parents), preference for more descriptive representation, perceptions of a link between descriptive and substantive representation of minorities, social distance from Whites, personal experience of discrimination and a composite scale measuring perceptions of discrimination against in-group and other minorities. Even though these were not controls in the baseline model, most of were still tested as potential mediators of candidate ethnicity effects (with interaction terms and main effects), as discussed in the main text.

${ }^{78}$ The short campaign is the month before the election. This is a constituency-party level variable.
} 
candidate ethnicity effects for Whites was feelings towards immigration. Using responses to the question, 'Which, if any, of the following words describe your feelings about immigration? (Please tick up to FOUR)' we coded the 77 per cent of respondents who said they were Angry, Disgusted, Uneasy or Afraid as having Antiimmigrant sentiment. ${ }^{79}$ This variable serves as a proxy for Islamophobia since Voas and Ling show all Islamophobes are anti-immigrant and there are relatively few antiimmigrants who are tolerant of Islam. ${ }^{80}$

For minorities we considered various attitudinal variables as potential moderators, including belief that Asian and Black MPs represent minorities better, preferences for more Asian and Black MPs, experience and frequency of discrimination, social distance from Whites, strength of Black/Asian identity relative to British identity, and perceptions of racial prejudice. For Muslims we considered whether strength of Muslim identity relative to British identity, frequency of worship with others and importance of religion were moderators of co-Muslim candidate ethnicity effects. ${ }^{81}$

\section{Results}

Table 2 shows the coefficients from four alternative-specific multinomial probit models of vote choice for Whites who voted for the Conservatives, Labour or Liberal Democrats. The first two terms are alternative-specific intercepts. The main effects of the control variables (those from 'Strength of party id' to 'Incumbent MP') operate in the directions expected. The coefficients for the only respondent-specific

\footnotetext{
${ }^{79} \mathrm{We}$ also considered a variable measuring the total number of these emotions mentioned, but this gave similar but less clear results.

${ }^{80}$ Voas and Ling 2008.

${ }^{81}$ Details of coding for all the attitudinal potential moderators for minorities are not given because they proved to be statistically insignificant.
} 
control show that public sector workers were less likely to vote Conservative than Labour. There was insufficient evidence that the effects of the alternative-specific controls depended on party, except for Distance from contention, for which the fitted interaction terms are in the models. ${ }^{82}$

TABLE 2 ABOUT HERE.

The four models are based on the same sample with the same controls but vary in the operationalization of candidate ethnicity effects. Model (1) shows that White voters were less likely to support ethnic minority candidates. The average electoral penalty was 4 percentage points of the three-party vote. ${ }^{83}$ The coefficient is only just statistical significant the 5 per cent level because the data are such that we do not have the statistical power to identify smaller effects.

Model (2) indicates that White voters were significantly less likely to vote for Muslim candidates. The average electoral penalty faced by Muslim candidates at the hands of White voters is 8 percentage points of the three-party vote, twice that for minorities on average. Model (3) suggests that most of the ethnic minority electoral

\footnotetext{
${ }^{82}$ Even after controls for strong indicators of party preference and predictors of vote choice, people are less likely to vote for a party that is running third (or lower) in their constituency. Since the main effect of distance from contention is negative and the interaction terms with Con and $L D$ are positive but smaller than the main effect, the model shows that Labour candidates suffer more from distance from contention effects (from tactical voting or differential abstention) than do Conservative and Labour candidates. Why this should be is not clear.

${ }^{83}$ For 'average' effects on the probability scale here and later on we take average marginal effects at the alternative-specific mean for each party and then average across parties (to deal with differences in baseline probabilities) and round to the nearest integer. See discussion of Table 3 for further details.
} 
penalty in Model (1) is specifically against Muslim candidates. The coefficient for ethnic minority candidature drops by a half and ceases to be statistically significant after controlling for Muslim candidature. The effect of Muslim candidature relative to that for other minority candidates is not statistically significant but the coefficient suggests a substantial difference. ${ }^{84}$

Two refinements are introduced in Model (4). ${ }^{85}$ First, we find that the effect of Muslim candidature differs between parties. The substantial positive coefficient of Conservative Muslim Candidate effectively means that Muslim candidates for the Tories did not suffer the same electoral penalty as those from the other two main parties. With only 16 Muslim Conservative candidates there could be some uncontrolled for issues peculiar to these individuals that might account for this finding. ${ }^{86}$

\footnotetext{
${ }^{84} \mathrm{We}$ also considered whether the particular ethnic group of the candidate mattered separately from Muslim/other. There is a severe multicolinearity problem, but it seems clear that it is Muslim status that is important rather ethnicity (results not shown).

${ }^{85}$ Both are statistically significant on their own but introduced together for reasons of space.

${ }^{86}$ Collectively, they were more likely than other Muslim candidates to be standing in constituencies where their party was third. Also whereas Labour and Liberal Democrat Muslims achieved very similar average vote shares to others from their parties, Tory Muslims averaged 22 per cent compared with 36 per cent for other Conservative candidates. While there does not seem to be evidence of a floor effect for Conservative Muslim candidates or a general tendency for Muslims not to suffer so much from strategic desertion, it does seem as though Tory Muslims were disproportionately in seats where Conservative candidates generally might have been relatively ignored and so their characteristics matter less. Alternatively it may be that they were better candidates with more party support in accordance with David Cameron's modernization strategy, but only one of the sixteen was on the A-list. There are also some signs than Indian candidates did better when they were standing for the Tories than for other parties.
} 
The second development in Model (4) tests the hypothesis that the anti-Muslim candidate effect is stronger for those who have anti-immigrant feelings. Thus Model (4) includes controls for the main effects of anti-immigrant feelings ${ }^{87}$ and an interaction between anti-immigrant sentiment and Muslim candidature, which is negative and statistically significant as expected. ${ }^{88}$ Since the main effect of Muslim candidature in Model (4) is not significant, it appears that the anti-Muslim candidate effect is predominantly driven by those with anti-immigrant sentiments.

Other potential moderating variables, for both ethnic minority and Muslim candidate effects, were found to be statistically insignificant. Thus we found insufficient evidence that candidate ethnicity effects were weaker in marginal constituencies, or for those further from contention, or where the minority candidate was the incumbent MP (by contrast with findings for US cities ${ }^{89}$ ). Similarly, ethnic electoral penalties are no weaker for those with strong party identification, or those contacted by the minority candidate's party. Unlike Carsey or Avery and Fine we found no tendency for the effect of minority candidature to depend on the ethnic composition of the constituency, ${ }^{90}$ nor for the Muslim candidate effect to be weaker where there is a greater proportion of Muslims, regardless of controlling for anti-immigrant sentiment.

Marginal effects (differences in predicted probabilities from the three-party choice)

\footnotetext{
${ }^{87}$ The Con*Anti-Immigrant and LD*Anti-Immigrant terms are insignificant because they are mediated by attitudes to the parties (analysis not shown).

${ }^{88}$ In further analysis not shown, the interaction effect between EM candidature and anti-immigrant feelings was not significant.

${ }^{89}$ Hajnal 2001.

${ }^{90}$ Avery and Fine 2009; Carsey 2009.
} 
from Model (4) are presented in Table 3 for different scenarios chosen to elucidate how the Muslim electoral penalty varies by party and the feelings of the voter towards immigrants. Each figure shows how the probability of voting for a party would change if they fielded a Muslim instead of a White candidate, while the other parties put up White candidates. The first row shows the effects for the threequarters of voters who have a negative emotional reaction to immigration and the second row gives the effects for those who do not. Control variables are set at their alternative-specific means (i.e. average strength of party identification for Labour for the predicted probability of voting Labour etc. $)^{91}$

\section{TABLE 3 ABOUT HERE}

The Conservative Muslim candidates were more popular than their White candidates among those without anti-immigrant sentiment, but for those with anti-immigrant feelings Muslim candidature made no practical difference: the positive Muslim Conservative effect is cancelled out by the more general anti-Muslim penalty for anti-immigrant voters. While the model identifies different effects for Conservatives compared with the other two parties, differences between the effect sizes for Labour and Liberal Democrats are entirely to do with differences in baseline probabilities. ${ }^{92}$ There is a negative effect of Muslim candidature for Labour and Liberal Democrats, which is weak and statistically insignificant for those without anti-immigrant feelings but over 10 points for Muslim candidates among anti-immigrant voters.

\footnotetext{
${ }^{91}$ Since voters at the mean are disproportionately likely to vote LD, the Party and Leader feeling scores were adjusted to 5 for Labour and 4 for the Liberal Democrats to ensure that the baseline probabilities came out close to the actual share of the vote. They were Con 41, Lab 37 and LD 23.

92 The effects are larger the closer the baseline probability is to 50 per cent.
} 
Turning to the electoral behaviour of ethnic minorities, Table 4 shows a similar set of alternative-specific multinomial probit models to those in Table 2, but estimated with ethnic minorities who voted for one of three main parties only. The control variables are similar, but with some minor variations. Pooled analysis of ethnic minorities all together revealed uniformly null results, albeit in the expected directions. These are not shown because they masked important differences between specific ethnic groups. The basis for each model is indicated in the first row. The control variables for all the models in Table 4 are the same and similar to those for the Whites, but with some minor variations. The principle for the selection of control variables was that anything significant for the pooled ethnic minority models should be included.

\section{TABLE 4 ABOUT HERE}

Model (1) shows that Pakistani and Bangladeshi Muslim voters ${ }^{93}$ were significantly more likely to vote for ethnic minority candidates overall if we ignore any tendency to prefer particular minorities. Model (2) shows a stronger tendency to vote for Muslim over non-Muslim candidates. But these co-minority and co-religion effects could both be driven by a co-ethnicity effect. Unfortunately it is not possible to sensibly directly test for a co-ethnicity effect for Bangladeshis because of the paucity of candidates from that group. ${ }^{94}$ So Models (3) and (4) are restricted to Pakistani Muslims only.

Model (3) shows that there is a strong co-ethnic candidate effect for Pakistanis, with

\footnotetext{
${ }^{93}$ The tiny number of non-Muslims from these groups were excluded for simplicity.

94 There were only four Bangladeshi candidates in constituencies where we also had Bangladeshi respondents, and three of these were in Bethnal Green and Bow.
} 
an average bonus of 8 percentage points over non-co-ethnic candidates. Model (4) is designed to identify the relative importance of co-minority, co-Muslim and co-ethnic candidate effects. The positive coefficient for ethnic minority candidature generally suggests that Pakistanis are more likely to vote for non-Muslim (including co-ethnic) minority candidates than Whites, but the effect is not statistically significant. The larger negative coefficient for Muslim candidates shows that Pakistanis are certainly not inclined to vote for non-Pakistani Muslim candidates, undermining the idea of a co-Muslim effect separate from a co-ethnic effect. ${ }^{95}$ Finally, despite the statistical insignificance of each separately, the combination of the substantial coefficient for minority candidates generally and the bigger additional bonus for being a co-ethnic candidate indicates that there is strong co-ethnic voting for Pakistanis. ${ }^{96}$

By contrast with the strong co-ethnic candidate effects for Pakistanis, we found no candidate ethnicity effects of any kind for Indians, Black Caribbeans or Black Africans. Because the results are similarly null for each of these groups separately Table 4 shows only two pooled models ( 5 and 6 ) for these groups. If anything the cominority and co-ethnicity effects are negative, even after excluding the small number of Muslim respondents who tend to weaken the chances of finding positive-co-ethnic effects. Since the candidature coefficients in these and similar models are clearly statistically insignificant, there is insufficient evidence for candidate ethnicity effects for these groups. ${ }^{97}$

\footnotetext{
95 There were 14 non-Pakistani Muslim candidates. Additional analysis (not shown) indicates that Bangladeshis were no more likely to vote for Pakistani Muslims than other minority candidates. ${ }^{96}$ Although we cannot identify it directly, further analysis (not shown) suggests that Bangladeshis behave similarly in this respect.

${ }^{97}$ This includes no tendencies to vote for or against other groups (e.g. Indians do not appear to discriminate against Pakistani candidates).
} 
The tests for the potential moderating effects discussed above were tested group by group, but all were found to be null or based on dangerously few cases. ${ }^{98}$ There was insufficient evidence that sensitivity to candidate ethnicity depended on strength of party identification, age or generation of immigration, ${ }^{99}$ education, religion, religiosity, relative strengths of ethnic and British identity, social distance from Whites, ${ }^{100}$ perceptions of discrimination (either personal or group based), ethnic density of the neighbourhood, marginality of the constituency, distance from contention, party and incumbency status of the ethnic minority candidate, ${ }^{101}$ preferences for descriptive representation or impressions of improved representation from Black and Asian MPs. Collectively these null findings suggest that co-ethnic voting is not the preserve of those who are least integrated and feel most alienated and discriminated against.

Perhaps the most striking of these null findings is that even those who thought that

\footnotetext{
${ }^{98}$ Co-ethnic voting does seem to be stronger when there was also contact with a co-ethnic canvasser (party worker) but there were so few respondents in this category that this result could easily be accidental and in any event appears to affect very few people.

${ }^{99}$ In line with claims that the political significance of biraderi is being challenged by young and second generation Pakistanis, there were negative interaction terms between co-ethnic candidature and each of age and generation, but they were far from statistically significant.

${ }^{100}$ There are sufficient amounts of self-reported social distance from Whites and since it is not linked to the strength of candidate ethnicity effects it seems unlikely that our null results are due to selfcensoring reported discriminatory behaviour of the kind identified by Terkildsen (1993). Concerns about racial prejudice for or against candidates is a not such a widely discussed issue in the UK as it is in the US.

${ }^{101}$ There were too few cases to examine this sensibly group by group. If anything, incumbents seem to benefit from more co-ethnic voting, not less.
} 
'Black and Asian MPs can better represent Black and Asian interests than White MPs can' and those who thought that 'getting more Black and Asian people into Parliament would improve things for ethnic minorities in Britain' were not significantly more likely to vote for an ethnic minority candidate (when there was one) than those who did not express such views in favour of greater descriptive representation. Although there was some sign that co-ethnic voting was stronger for those Pakistanis who wanted more descriptive representation for Blacks and Asians, the effect was not statistically significant (perhaps largely because this question was on the mail-back supplement which achieved a low response rate). Nonetheless, in general, demand for descriptive representation does not seem to generate more votes for Britain's ethnic minority candidates.

\section{Conclusions}

To summarize, the evidence from the last general election shows that White British voters on average are less willing to vote for ethnic minority candidates, especially Muslim candidates. The anti-Muslim-candidate effect was largely absent for the quarter of White voters who expressed no anti-immigrant sentiment. For reasons that are not clear from the data, the 16 Muslim Conservative candidates were more popular than their White counterparts. Candidate ethnicity effects for ethnic minority voters seem to be limited to Pakistani and Bangladeshi voters. For Pakistanis, coMuslim voting is entirely driven by strong co-ethnic voting. There were too few Bangladeshi candidates to test for co-ethnic voting for Bangladeshis, but they appear to respond to candidate ethnicity similarly.

The relative unwillingness of specifically anti-immigrant Whites to vote for Muslim candidates together with the known positive association between anti-immigrant sentiment and Islamophobia suggests that the Muslim-candidate electoral penalty is 
driven by prejudice and discrimination. Our results are consistent with those who claim that Muslims face more hostility in general than other minority groups in Britain.

Although Conservative Muslim candidates did better than their White counterparts, our models suggest that they would have done even better were it not for the Muslim electoral penalty delivered by anti-immigrant Whites. Among the possible explanations for the relative success of Conservative Muslims is that they were 'better' candidates than the Labour and Liberal Democrat Muslims. Perhaps Muslim Conservatives are much more highly assimilated into White society than Muslims in other parties, or maybe the Tories have a selection process that discriminates more heavily in favour of candidates that will be attractive to White voters.

The strong co-ethnic voting among Pakistanis (and perhaps Bangladeshis) accords with the qualitative evidence on the social and political organization of this group, including claims about the importance of kinship networks. Given the high demand among ethnic minorities in Britain for better descriptive representation, it is maybe surprising that we did not find stronger and more widespread co-minority and coethnic candidate effects. In particular, why are those who want more descriptive representation not much more likely to vote for it? It could be that for minorities switching parties to gain descriptive representation comes at too great a loss of substantive representation. Whereas White voters often view the parties as rather similar and so incur little cost on substantive representation by reacting to candidate ethnicity, typically ethnic minority voters believe that Labour are much more likely than other parties are to look after the interests of Black and Asian people. ${ }^{102}$ So, not only do they therefore vote Labour disproportionately, but also it is a much greater

\footnotetext{
${ }^{102}$ Heath et al. 2013.
} 
compromise for ethnic minorities to desert Labour in the hope of securing another ethnic minority MP. Moreover, it is perhaps not surprising that candidate ethnicity does not matter so much for the minority of Blacks and Asians who are not inclined to vote Labour despite the policy differences on issues of race relations.

Since there are good reasons why preferences for descriptive representation might not lead ethnic minorities to vote disproportionately for minority candidates, the absence of such behaviour provides no excuse for ignoring demands to redress the under-representation of ethnic minorities in parliament. Although it is not clear whether descriptive representation leads to better substantive representation, ${ }^{103}$ cross-national panel data suggest that greater minority descriptive representation leads to greater social respect for marginalized groups. ${ }^{104}$

Finally, while some research on the US shows that fielding ethnic minority candidates has the benefit of generating support from minority voters, our null findings suggest that that any such benefits appear to be uncertain at best. Moreover, in the case of Muslim candidates, at least from Labour and the Liberal Democrats, any gains from co-ethnic Muslim voters would be outweighed by the costs associated with loss of support from White voters in the vast majority of constituencies where Whites are the overwhelming majority. Nonetheless, the fears of many local party candidate selectors that ethnic minority candidates generally will suffer substantial discrimination at the ballot box seem unfounded.

\footnotetext{
$\overline{{ }^{103} \text { Saalfeld and Kyriakopoulou } 2011 .}$

${ }^{104}$ Ruedin 2009.
} 


\section{References}

Allport, Gordon Willard. 1954. The nature of prejudice. Cambridge, Mass: AddisonWesley.

Arrow, Kenneth J. 1998. What Has Economics to Say about Racial Discrimination? The Journal of Economic Perspectives 12(2): 91-100.

Avery, James M., and Jeffrey A Fine. 2011. Racial Composition, White Racial Attitudes, and Black Representation: Testing the Racial Threat Hypothesis in the United States Senate. Political Behavior 34(3): 391-410.

Banducci, Susan A., Todd Donovan, and Jeffrey A. Karp. 2004. Minority Representation, Empowerment, and Participation. The Journal of Politics 66(02): 534-556.

Barreto, Matt A. 2007. !Sí Se Puede! Latino Candidates and the Mobilization of Latino Voters. American Political Science Review 101(3): 425-441.

Becker, G. 1957. The economics of discrimination. Chicago: Chicago University Press.

Benson, Brett V., Jennifer L Merolla, and John G. Geer. 2011. Two steps forward, one step back? Bias in the 2008 presidential election. Electoral Studies 30(4): 607-620.

Bergh, Johannes, and Tor Bjorklund. 2011. The Revival of Group Voting: Explaining the Voting Preferences of Immigrants in Norway. Political Studies 59(2): 308-327.

Bird, Karen, Thomas Saalfeld, and Andreas M. Wust, eds. 2011. The Political Representation of Immigrants and Minorities: Voters, parties and parliaments in liberal democracies. Abingdon: Routledge.

Black, Jerome H., and Lynda Erickson. 2006. Ethno-racial Origins of Candidates and Electoral Performance: Evidence from Canada. Party Politics 12: 541461.

Bowyer, Benjamin T. 2009. The Contextual Determinants of Whites' Racial Attitudes in England. British Journal of Political Science 39(03): 559-586.

Buttice, Matthew K., and Caitlin Milazzo. 2011. Candidate positioning in Britain. Electoral Studies 30(4): 848-857.

Butler, Daniel M., and David E. Broockman. 2011. Do Politicians Racially Discriminate Against Constituents? A Field Experiment on State Legislators. American Journal of Political Science 55(3): 463-477.

Campbell, Rosie, and Philip Cowley. 2013. What Voters Want: Reactions to Candidate Characteristics in a Survey Experiment. Political Studies.

Carsey, Thomas M. 2009. The Contextual Effects of Race on White Voter Behavior: The 1989 New York City Mayoral Election. The Journal of Politics 57(01): 221-228.

Clarke, Harold, David Sanders, Marianne Stewart and Paul Whiteley. 2012. British Election Study In Person Pre and Post Election Survey Data [computer file]. Available from http://www.bes2009-10.org, accessed 15 June 2012.

Clarke, Harold, David Sanders, Marianne Stewart and Paul Whiteley. 2010. British Election Study Campaign Internet Panel Survey Data [computer file]. Available from http://www.bes2009-10.org, accessed 23 June 2010.

Collet, Christian. 2005. Bloc Voting, Polarization, and the Panethnic Hypothesis: The Case of Little Saigon. The Journal of Politics 67(3): 907-933.

Cowley, Philip. 2013. Why not ask the audience? Understanding the public's representational priorities. British Politics 8(2): 138-163.

Creegan, Chris, and Chloe Robinson. 2008. Prejudice and the workplace. In British Social Attitudes: The 24th report, London: Sage, p. 127-138.

Curtice, John, Stephen Fisher, and Robert Ford. 2010. Appendix 2: An Analysis of the Results. Pp. 385-426 in The British General Election of 2010 by Dennis 
Kavanagh and Philip Cowley. Basingstoke: Palgrave MacMillan.

Curtice, John, Stephen Fisher, and Michael Steed. 2005. Appendix 2: The Results Analysed. P p. 235-259 in The British General Election of 2005 by Dennis Kavanagh and David Butler. Basingstoke: Palgrave Macmillan.

Curtice, John, and Michael Steed. 1997. Appendix 2 The Results Analysed. Pp. 295325 in The British General Election of 1997 by David Butler and Dennis Kavanagh. Basingstoke: Macmillan.

Cutler, Fred. 2002. The Simplest Shortcut of All: Sociodemographic Characteristics and Electoral Choice. The Journal of Politics 64(2): 466-490.

Dancygier, Rafaela. 2010. Immigration and conflict in Europe. Cambridge University Press.

Field, Clive D. (2011). Revisiting Islamophobia in contemporary Britain: opinionpoll findings for 2007-10. In Marc Helbling (ed.) Islamophobia in the West: Measuring and Explaining Individual Attitudes, London: Routledge

Fieldhouse, Edward, and David Cutts. 2008. Diversity, density and turnout: The effect of neighbourhood ethno-religious composition on voter turnout in Britain. Political Geography 27: 530-548.

Ford, Robert. 2008. Is racial prejudice declining in Britain? The British Journal of Sociology 59(4): 609-636.

Ford, Robert. 2011. Acceptable and Unacceptable Immigrants: How Opposition to Immigration in Britain is Affected by Migrants' Region of Origin. Journal of Ethnic and Migration Studies 37(7): 1017-1037.

Ford, Robert, and Matthew J Goodwin. 2010. Angry White Men: Individual and Contextual Predictors of Support for the British National Party. Political Studies 58(1): 1-25.

Garbaye, Romain. 2002. Ethnic minority participation in British and French cities: a historical-institutionalist perspective. International Journal of Urban and Regional Research 26(3): 555-570.

Geddes, Andrew. 2001. Explaining ethnic minority representation: Contemporary trends in the shadow of the past. British Elections and Parties Review 11(1): 119-135.

Geddes, Andrew. 1995. The 'Logic' of Positive Action? Ethnic Minority Representation in Britain after the 1992 General Election. Party Politics 1(2): 275-285.

Goodhart, David. 2012. Making sense of Bradford West. Prospect Magazine.

Griffin, John D., and Michael Keane. 2006. Descriptive representation and the composition of African American turnout. American Journal of Political Science 50(4): 998-1012.

Hajnal, Zoltan L. 2001. White Residents, Black Incumbents, and a Declining Racial Divide. American Political Science Review 95(03): 603-617.

Heath, Anthony F., Stephen D. Fisher, Gemma Rosenblatt, David Sanders, and Maria Sobolewska. 2013. The Political Integration of Ethnic Minorities in Britain. Oxford: Oxford University Press.

Heath, Anthony F, Stephen D. Fisher, David Sanders, and Maria Sobolewska. 2011. Ethnic Heterogeneity in the Social Bases of Voting at the 2010 British General Election. Journal of Elections, Public Opinion \& Parties 21(2): 255-277.

Heath, Anthony, Stephen D. Fisher, David Sanders, and Maria Sobolewska. 2012. British Election Study Ethnic Minority Survey, 2010 [computer file]. Colchester, Essex: UK Data Archive [distributor], April 2012. SN: 6970, http://dx.doi.org/10.5255/UKDA-SN-6970-1

Hewstone, Miles, Mark Rubin, and Hazel Willis. 2002. Intergroup Bias. Annual review of Psychology 53(1): 575-604.

Highton, Benjamin. 2004. White Voters and African American Candidates for 
Congress. Political Behavior 26(1): 1-25.

Jacobson, Gary C. 1989. Strategic politicians and the dynamics of US House elections, 1946-86. American Political Science Review 83(3): 773-793.

Juenke, Eric Gonzalez, and Robert R. Preuhs. 2012. Irreplaceable Legislators? Rethinking Minority Representatives in the New Century. American Journal of Political Science 56(3): 705-715.

Kam, Cindy D. 2007. Implicit Attitudes, Explicit Choices: When Subliminal Priming Predicts Candidate Preference. Political Behavior 29(3): 343-367.

Kirkup, James. 2011. Tory chief Baroness Warsi attacks 'bigotry' against Muslims. The Telegraph. $19^{\text {th }}$ January 2011.

Laurence, Jonathan, and Rahsaan Maxwell. 2012. Political Parties and Diversity in Western Europe. In Immigrant Politics: Race and Representation in Western Europe, eds. Terri Givens and Rahsaan Maxwell. Lynne Rienner Pub, p. 1331.

Le Lohé, Michel J. 1998. Ethnic Minority Participation and Representation in the British Electoral System. In Race and British electoral politics, Shamit Saggar, ed. London: UCL Press.

Le Lohé, Michel J. 1993. Ethnic minority candidates in general elections. The Political Quarterly 64(1): 107-117.

Lewis-Beck, Michael S., Charles Tien, and Richard Nadeau. 2010. Obama's Missed Landslide: A Racial Cost? PS: Political Science and Politics 43(01): 69-76.

Long, J. Scott, and Jeremy Freese. 2005. Regression Models for Categorical Dependent Variables Using Stata, Second Edition. 2nd ed. Stata Press.

Lublin, David I. 1994. Quality, Not Quantity: Strategic Politicians in U.S. Senate Elections, 1952-1990. The Journal of Politics 56(1): 228-241.

Lublin, David, Thomas L. Brunell, Bernard Grofman, and Lisa Handley. 2011. Has the Voting Rights Act Outlived Its Usefulness? In a Word, 'No'. Legislative Studies Quarterly 34(4): 525-553.

Mcdermott, Monika L. 1998. Race and Gender Cues in Low-Information Elections. Political Research Quarterly 51(4): 895-918.

Michon, Laure, and Jean Tillie. 2011. 2.3 The Netherlands. Pp. 76-79 in The Political Representation of Immigrants and Minorities: Voters, parties and parliaments in liberal democracies, edited by Karen Bird et al. Abingdon: Routledge.

Modood, Tariq. 1992. Not Easy Being British. Stoke-on-Trent: Trentham.

Mortimore, Roger. 2002. Effect Of Candidate Ethnicity In The British General Elections Of 1997 and 2001. Available from http://www.ipsosmori.com/newsevents/ca/308/Effect-Of-Candidate-Ethnicity-In-The-BritishGeneral-Elections-Of-1997-And-2001.aspx, accessed 7 November 2011.

Muttarak, Raya, and Anthony Heath. 2010. Who intermarries in Britain? Explaining ethnic diversity in intermarriage patterns. The British Journal of Sociology 61(2): 275-305.

Norris, Pippa, Andrew Geddes, and Joni Lovenduski. 1992. Race and parliamentary representation. British Elections and Parties Yearbook.

Norris, Pippa (2010) British General Election Constituency Results Release 5.0. Available from http://www.hks.harvard.edu/fs/pnorris/Data/Data.htm, accessed 30 June 2010.

Operation Black Vote. 2008. How to Achieve Better BME Political Representation. London: Government Equalities Office.

Pantoja, Adrian D, and Gary M. Segura. 2003. Does Ethnicity Matter? Descriptive Representation in Legislatures and Political Alienation Among Latinos Social Science Quarterly 84(2): 441-460.

Peach, Ceri. 1996. Does Britain Have Ghettos? Transactions of the Institute of 
British Geographers 21(1): 216-235.

Pettigrew, Thomas F. 1998. Intergroup Contact Theory. Annual review of psychology 49(1): 65-85.

Philpot, Tasha S., and Hanes Walton. 2007. One of our own: Black female candidates and the voters who support them. American Journal of Political Science 51(1): 49-62.

Rallings, Colin, and Michael Thrasher. 2007. British Electoral Facts, 1832-2006. Aldershot: Ashgate.

Ruedin, Didier. 2009. Ethnic Group Representation in a Cross-National Comparison. The Journal of legislative studies 15(4): 335-354.

Robinson, W. 1950. Ecological Correlations and the Behavior of Individuals. American Sociological Review 15(3): 351-357.

Saggar, Shamit, and Andrew Geddes. 2000. Negative and positive racialisation: Reexamining ethnic minority political representation in the UK. Journal of Ethnic and Migration Studies. 26(1): 25-44.

Saggar, Shamit, and Anthony Heath. 1999. Race: Towards a Multicultural Electorate? Pp. 102-147 in Critical Elections: British Parties and Voters in Long-Term Perspective, edited by Geoffrey Evans and Pippa Norris. London: Sage.

Saalfeld, Thomas, and Kalliopi Kyriakopoulou. 2011. Presence and behaviour: black and minority ethnic MPs in the British House of Commons. Pp. 230-249 in The Political Representation of Immigrants and Minorities: Voters, parties and parliaments in liberal democracies, edited by Karen Bird et al. Abingdon: Routledge.

Sigelman, Carol K., Lee Sigelman, Barbara J. Walkosz and Michael Niz. 1995. Black candidates, White voters: Understanding racial bias in political perceptions. American Journal of Political Science. 39(1): 243-265.

Sobolewska, Maria (2013) Party strategies, political opportunity structure and the descriptive representation of ethnic minorities in Britain. West European Politics. 36, 3:615-33.

Solomos, John, and Les Back. 1995. Race, Politics and Social Change. London: Routledge.

Speaker's Conference on Parliamentary Representation (2009) Speaker's Conference on Parliamentary Representation - Final Report. Available from http://www.publications.parliament.uk/pa/spconf/239/23907.htm\#a12, accessed 1 June 2011.

Statham, Paul. 1999. Political mobilisation by minorities in Britain: Negative feedback of 'race relations'? Journal of Ethnic and Migration Studies 25(4): 597-626.

Stegmaier, Mary, Michael S. Lewis-Beck, and Kaat Smets. 2013. Standing for Parliament: Do Black, Asian and Minority Ethnic Candidates Pay Extra? Parliamentary Affairs 66(2): 268-285.

Squire, Peverill. 1992. Challenger Quality and Voting Behavior in U. S. Senate Elections. Legislative Studies Quarterly 17(2): 247-263.

Tate, Katherine. 1991. Black Political Participation in the 1984 and 1988 Presidential Elections. American Political Science Review 85(4): 1159-1176.

Teney, Celine, Dirk Jacobs, Andrea Rea and Pascal Delwit. 2010. Ethnic voting in Brussels: Voting patterns among ethnic minorities in Brussels (Belgium) during the 2006 local elections. Acta politica 45(3): 273-297.

Terkildsen, Nayda. 1993. When White voters evaluate black candidates: The processing implications of candidate skin color, prejudice, and self-monitoring. American Journal of Political Science. 37(4): 1032-1053.

Train, Kenneth. 2003. Discrete Choice Methods with Simulation. Cambridge: 
Cambridge University Press.

Voas, David, and Rodney Ling. 2008. Religion in Britain and the United States. In British Social Attitudes: The 26th Report, London: Sage, p. 39-64.

Voci, Alberto. 2010. The link between identification and in-group favouritism: Effects of threat to social identity and trust-related emotions. British Journal of Social Psychology 45(2): 265-284.

Wells, Anthony. 2011.911 Ten Years On. Available from http://ukpollingreport.co.uk/blog/archives/4002, accessed 12 September 2011.

Wolfinger, Raymond E. 1965. The Development and Persistence of Ethnic Voting. American Political Science Review 59(4): 896-908.

Wood, Martin, Jon Hales, Susan Purdon, Tanja Sejersen and Oliver Hayllar. 2009. A test for racial discrimination in recruitment practice in British cities.

Department for Work and Pensions Research Report 607. 
Table 1 Numbers of Ethnic Minority Candidates and MPs 1979-2010

\begin{tabular}{ccccccccccc}
\hline & \multicolumn{2}{c}{ Conservative } & \multicolumn{2}{c}{ Labour } & \multicolumn{2}{c}{ Liberal Democrat } & \multicolumn{2}{c}{ Total EM } & \multicolumn{2}{c}{ All major party } \\
& Cands & MPs & Cands & MPs & Cands & MPs & Cands & MPs & Cands & MPs \\
\hline 1979 & 2 & 0 & 1 & 0 & 2 & 0 & 5 & 0 & 1822 & 619 \\
1983 & 4 & 0 & 6 & 0 & 8 & 0 & 18 & 0 & 1899 & 629 \\
1987 & 6 & 0 & 14 & 4 & 9 & 0 & 29 & 4 & 1899 & 627 \\
1992 & 8 & 1 & 9 & 5 & 5 & 0 & 22 & 6 & 1900 & 627 \\
1997 & 9 & 0 & 13 & 9 & 17 & 0 & 39 & 9 & 1918 & 629 \\
2001 & 16 & 0 & 21 & 12 & 29 & 0 & 66 & 12 & 1919 & 630 \\
2005 & 41 & 2 & 32 & 13 & 40 & 0 & 113 & 15 & 1880 & 615 \\
2010 & 45 & 11 & 49 & 16 & 44 & 0 & 138 & 27 & 1893 & 621 \\
\hline
\end{tabular}

Source: Rallings and Thrasher (2007) GB, three main parties only, with authors' own figures for 2010. 
Table 2 Alternative-specific multinomial probit models of major party vote choice for Whites

\begin{tabular}{|c|c|c|c|c|}
\hline & $(1)$ & $(2)$ & $(3)$ & $(4)$ \\
\hline \multicolumn{5}{|l|}{ Party (baseline $=$ Labour) } \\
\hline \multirow[t]{2}{*}{ Con } & $0.21^{* * *}$ & $0.21^{* * *}$ & $0.21^{* * *}$ & 0.14 \\
\hline & $(0.06)$ & $(0.06)$ & $(0.06)$ & $(0.12)$ \\
\hline \multirow[t]{2}{*}{ LD } & $0.53^{* * *}$ & $0.53^{* * *}$ & $0.53^{* * *}$ & $0.56^{* * *}$ \\
\hline & $(0.07)$ & $(0.07)$ & $(0.07)$ & $(0.10)$ \\
\hline \multirow[t]{2}{*}{ Strength of party id } & $0.39^{* * *}$ & $0.39^{* * *}$ & $0.39^{* * * *}$ & $0.39^{* * *}$ \\
\hline & $(0.03)$ & $(0.03)$ & $(0.03)$ & $(0.03)$ \\
\hline \multirow[t]{2}{*}{ Party like score } & $0.37^{* * *}$ & $0.37^{* * *}$ & $0.37^{* * * *}$ & $0.37^{* * *}$ \\
\hline & $(0.03)$ & $(0.03)$ & $(0.03)$ & $(0.03)$ \\
\hline \multirow[t]{2}{*}{ Leader like score } & $0.13^{* * *}$ & $0.13^{* * *}$ & $0.13^{* * * *}$ & $0.13^{* * *}$ \\
\hline & $(0.02)$ & $(0.02)$ & $(0.02)$ & $(0.02)$ \\
\hline \multirow[t]{2}{*}{ Pty best Most Impt Issue } & $0.68^{* * *}$ & $0.68^{* * *}$ & $0.68^{* * *}$ & $0.68^{* * *}$ \\
\hline & $(0.06)$ & $(0.06)$ & $(0.06)$ & $(0.06)$ \\
\hline \multirow[t]{2}{*}{ Contacted by party } & $0.59^{* * *}$ & $0.59^{* * *}$ & $0.59^{* * * *}$ & $0.59^{* * *}$ \\
\hline & $(0.08)$ & $(0.08)$ & $(0.08)$ & $(0.08)$ \\
\hline \multirow[t]{2}{*}{ Shrt Campaign Spend / Limit } & $0.32^{* * *}$ & $0.32^{* * *}$ & $0.32^{* * * *}$ & $0.33^{* * *}$ \\
\hline & $(0.10)$ & $(0.09)$ & $(0.09)$ & $(0.10)$ \\
\hline \multirow[t]{2}{*}{ Dist from contention } & $-0.06^{* * *}$ & $-0.06^{* * *}$ & $-0.06^{* * *}$ & $-0.06^{* * *}$ \\
\hline & $(0.01)$ & $(0.01)$ & $(0.01)$ & $(0.01)$ \\
\hline \multirow[t]{2}{*}{ Con $*$ Dist from cont } & $0.04^{* * * *}$ & $0.04^{* * *}$ & $0.04^{* * *}$ & $0.04^{* * *}$ \\
\hline & $(0.01)$ & $(0.01)$ & $(0.01)$ & $(0.01)$ \\
\hline \multirow[t]{2}{*}{ LD * Dist from cont } & $0.04^{* * * *}$ & $0.04^{* * *}$ & $0.04^{* * *}$ & $0.04^{* * *}$ \\
\hline & $(0.01)$ & $(0.01)$ & $(0.01)$ & $(0.01)$ \\
\hline \multirow[t]{2}{*}{ Con $*$ Public Sector } & $-0.24^{* *}$ & $-0.24^{* *}$ & $-0.24^{* *}$ & $-0.24^{* *}$ \\
\hline & $(0.09)$ & $(0.09)$ & $(0.09)$ & $(0.09)$ \\
\hline \multirow[t]{2}{*}{ LD * Public Sector } & -0.09 & -0.08 & -0.09 & -0.09 \\
\hline & $(0.08)$ & $(0.08)$ & $(0.08)$ & $(0.08)$ \\
\hline \multirow[t]{2}{*}{ Incumbent MP } & $0.17^{* * *}$ & $0.17^{* * *}$ & $0.17^{* * *}$ & $0.17^{* * *}$ \\
\hline & $(0.05)$ & $(0.05)$ & $(0.05)$ & $(0.05)$ \\
\hline \multirow[t]{2}{*}{ EM Candidate } & $-0.15^{*}$ & & -0.07 & -0.07 \\
\hline & $(0.08)$ & & $(0.09)$ & $(0.09)$ \\
\hline \multirow[t]{2}{*}{ Muslim Candidate } & & $-0.28^{*}$ & -0.22 & -0.12 \\
\hline & & $(0.12)$ & $(0.15)$ & $(0.28)$ \\
\hline \multirow{2}{*}{ Con Muslim Candidate } & & & & $0.75^{* *}$ \\
\hline & & & & $(0.29)$ \\
\hline \multirow[t]{2}{*}{ LD Muslim Candidate } & & & & 0.13 \\
\hline & & & & $(0.26)$ \\
\hline \multirow[t]{2}{*}{ Con $*$ Anti Immigrant } & & & & 0.07 \\
\hline & & & & $(0.12)$ \\
\hline \multirow[t]{2}{*}{ LD * Anti Immigrant } & & & & -0.03 \\
\hline & & & & $(0.10)$ \\
\hline \multirow{2}{*}{$\begin{array}{l}\text { Muslim Candidate } \\
\quad * \text { Anti Immigrant }\end{array}$} & & & & $-0.55^{*}$ \\
\hline & & & & $(0.27)$ \\
\hline$B I C$ & 6118.50 & 6116.82 & 6126.57 & 6167.45 \\
\hline
\end{tabular}

Notes: N (respondents) = 10131. Standard errors in parentheses. Source: BES 2010 Campaign Internet Panel Study, post-wave. White respondents only. ${ }^{*} p<0.05,{ }^{* *} p<0.01,{ }^{* * *} p<0.001$ 
Table 3 Effects on voting probabilities for Whites in response to Muslim candidature (relative to White candidature) when other parties have White candidates

\begin{tabular}{lccc}
\hline & Conservative & Labour & Lib Dem \\
\hline Change in probability if: & & & \\
Voter is anti-immigrant & +0.4 & -17.6 & -12.3 \\
Voter is not anti-immigrant & +19.8 & -5.0 & -1.5 \\
\end{tabular}

Note: Change figures are percentage points. Simulations from Model (4) in Table 2. See text for more details. 
Table 4 Alternative-specific multinomial probit models of major party vote choice for ethnic minorities

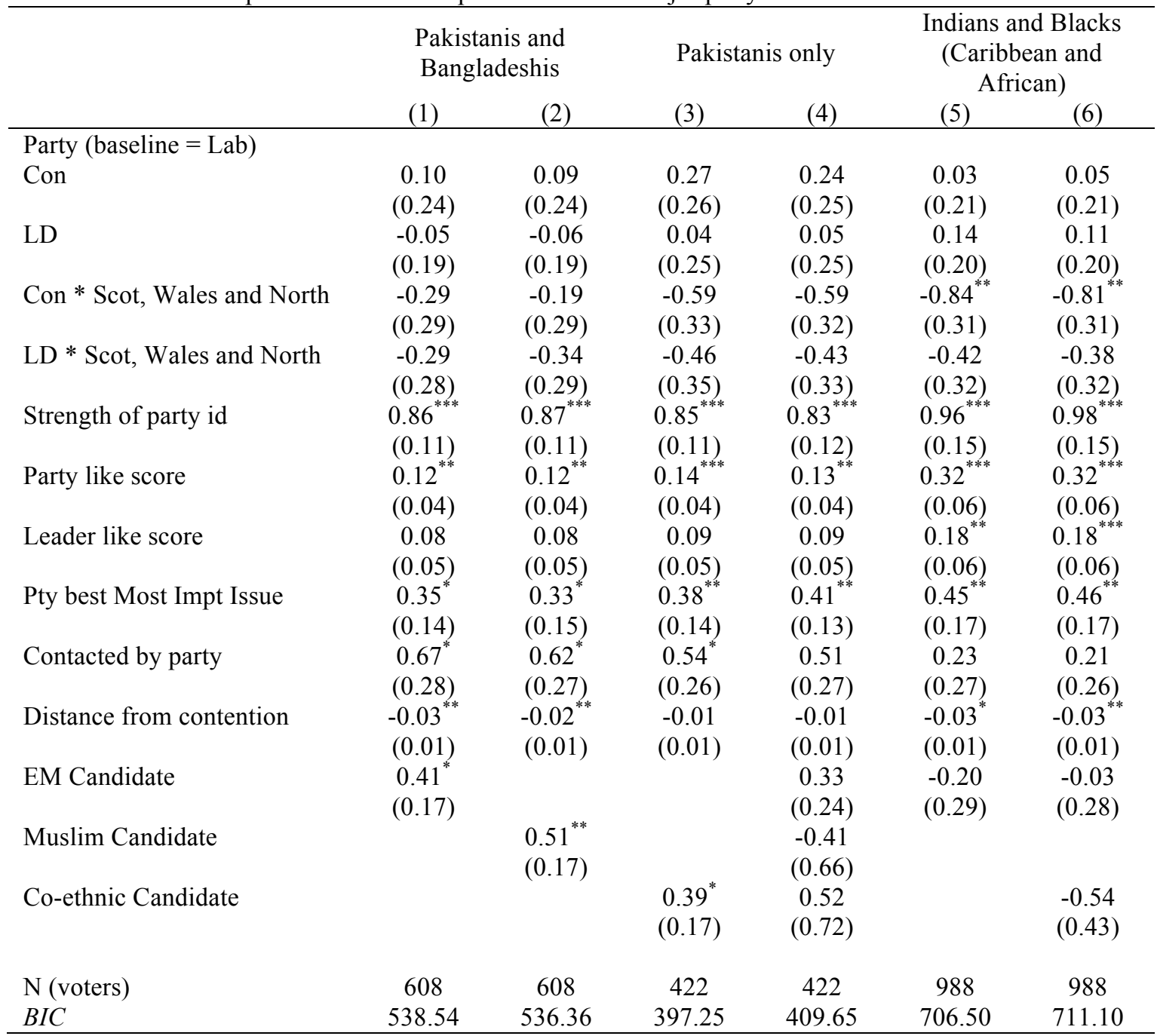

Notes: Muslims only in models 1 to 4; non-Muslims only in models 5 and 6. Standard errors in parentheses. Source: EMBES and BES 2010 Post-election surveys. ${ }^{*} p<0.05,{ }^{* *} p<0.01,{ }^{* * *} p<0.001$ 